\title{
PROFESSIONAL AND PERSONAL DEVELOPMENT, QUALITY DEVELOPMENT: COMPETENCE REQUIREMENTS OF A MODERN NURSE IN SWITZERLAND
}

\section{Irena Khmilyar ${ }^{1}$}

DOI: https://doi.org/10.30525/978-9934-26-076-6-16

Modern health care system in Switzerland requires highly qualified specialists, particularly, mid-level medical workers, able to perform professional functions at a high level. Thus, it is necessary to analyze vocational training of nurses in the context of the demands of society, labour market needs and legal framework, according to which training of these professionals is implemented.

\footnotetext{
${ }^{1}$ Lviv Polytechnic National University, Ukraine
} 
Requirements for core competencies have been elaborated by the Swiss Nurses Association, which is actively involved in the development of the nursing profession. The document «Professionelle Pflege Schweiz - Perspektive 2020» outlines the prospects for the development of the nursing profession, and defines the requirements for competence and quality standards of nursing [3]. It is should be noted that the outlined requirements meet the international trends of nursing profession development [2].

The list of competencies, the formation of which is aimed at the efforts of the system of professional training of medical staff, includes such competence as «Professional, personal, and quality development». Currently, a licensed practical nurse is considered not only as an executor of doctor's orders or doctor's assistant. Also, she is a full-fledged and self-sufficient specialist, taking an active part in the development of nursing. Thus, Nursing Care Continuum Framework and Competencies necessitates the acquisition of such competencies which include the ability to: use knowledge of professional standards and best practice in their own activities; promote and maintain a positive image of the nurse; act as an effective role model for applicants and auxiliary medical staff; promote the development of policies in the field of health care and social aid; ensure the access to high-quality services [2]. It is noteworthy that, at the beginning of the XXI century a significant role is given to practitioners in further development of the nursing profession. Thus, it is possible to take into account not only theoretical achievements of researchers in the field of nursing, but also the experience of practicing nurses, which helps analyze peculiarities of the profession from a theoretical and pragmatic perspective, identifying its advantages and disadvantages, serves as a basis for improving initial training programs and developing proposals for improving qualifications on an ongoing basis.

The relevant competence for a registered nurse determines the availability of the ability to distribute, use, monitor and review standards of the profession and best practice guidelines; promote and maintain a positive image of a nurse; become a role model for students and other members of professional care team; act as a resource for students, other members of health care team and the community in general; promote the development of nursing and raising the standards of professional care; be aware of new practice, trends, current problems in nursing; promote the development of policies in the field of health care and social aid; ensure access to high-quality services [2].

Undoubtedly, a registered nurse must be able to take responsibility for performing tasks as prescribed and in accordance with policies, procedures, quality measures and with the consideration of the level of training, as well as participate in quality improvement and quality assurance procedures. 
The final, particularly significant competence, required for a registered nurse, is the competence to study on a continuous basis, which cover a regular review of own practice, reflection, expert assessment, as well as responsibility for lifelong learning, professional development and maintenance of competence. "One of the methods of quality management of nurses' work in health care institutions is to conduct scientific and practical seminars, conferences, introduction of projects and programmes aimed at improving the quality of medical care delivery to the population» [1, p. 37].

Thus, according to performed analysis, now the scope of the professional functions of a nurse is expanding in Switzerland It is not just about providing services on the organization of medical care for patients, but also actively participating in the development of the profession of nursing, ensuring the quality provision of medical services, which are impossible to be realized without the potential of continuous education.

\section{References:}

1. Halapats N. B. (2014) Upravlinnia yakistiu roboty medsestrynskoi sluzhby Lvivskoi oblasti. Medsestrynstvo, (2), 35-39.

2. Nursing Care Continuum Framework and Competencies. Geneva, Switzerland: International Council of Nurses. (2008). Retrieved from: https://siga-fsia.ch/files/ user_upload/07_ICN_Nursing_Care_Continuum_Framework_and_Competencies.pdf

3. SBK-ASI. Professionelle Pflege Schweiz - Perspektive 2020. Bern: Schweizer Berufsverband der Pflegefachfrauen und Pflegefachmanner (2011). Retrieved from: http://www.sbk.ch/fileadmin/sbk/shop_downloads/de/Perspektive2020-dt.pdf 